RESEARCH ARTICLE

\title{
Modulating the Metabolic Activity of Silkworm, Bombyx mori L. with the Supplementation of Honey and Protein Sources
}

Aruna R and Murugesh K A

Department of Sericulture, Forest College \& Research Institute, Tamil Nadu Agricultural University, Mettupalayam - 641301

\begin{abstract}
The present study aimed to assess the effect of honey obtained from different bee species and protein sources on the metabolic changes in mulberry silkworm, Bombyx mori L. The results of experiment showed that oral administration of honey and protein sources to silkworm larvae during late-age instars daily once significantly changed metabolic processes. Among the various treatments and concentrations tested, 5 per cent Trigona iridipennis honey significantly increased the carbohydrate in haemolymph $(16.71 \mathrm{mg} / \mathrm{mL})$ and fat body $(12.38 \mathrm{mg} / \mathrm{g})$ over all other treatments. The lipid content in haemolymph $(23.03 \mathrm{mg} / \mathrm{mL})$ and fat body $(45.38 \mathrm{mg} / \mathrm{g})$ of silkworm were also found to be superior in the larval batch treated with 5 per cent T. iridipennis. Apart from this, the same treatment was showed statistical superiority in increasing the activity of enzymes viz., aspartate aminotransferase $(269.78 \mu \mathrm{g} / \mathrm{mL})$ and alanine aminotransferase $(563.25$ $\mu \mathrm{g} / \mathrm{mL}$ ), which play an important role in protein metabolism.
\end{abstract}

Keywords: Aminotransferase; Carbohydrate; Haemolymph; Fat body; Metabolism; Honey

\section{INTRODUCTION}

The silkworm, Bombyx mori L, secretes silk, a continuous and lustrous fibre having high value. The larval development and silk secreting ability of silkworm depend on the nutritional composition of food, the mulberry (Morus spp.) (Seidavi et al., 2005; Kantwa et al., 2006). Generally, the mulberry leaves contain the required amount of nutrients essential for the optimal growth and development of silkworms. However, the frequent and continuous harvesting of leaves and the inadequate quantity of fertilizers lead to the deprivation of nutrients by the silkworm. More often, this results in complete or partial reduction in cocoon and raw silk yield, ultimately huge economic loss to the farmers. This situation can best be managed by feeding the silkworm with nutritionally enriched mulberry leaves. A wide array of studies conducted on the enrichment of mulberry with various exogenous modulators having essential nutrients viz., vitamins, enzymes, hormones, minerals and amino acids have shown significant enhancement in biological as well as the cocoon characters of silkworm (Khan and Saha, 1995; Etebari et al., 2004; Bhattacharya and Kaliwal, 2005; Rahmathulla et al., 2007; Radjabi et al., 2010; Chakrabarthy and Kaliwal, 2012; Kavitha et al., 2014). One such exogenous modulator that has attracted the attention of researchers is honey
(Council of European Union, 2002). Honey contains various bioactive components in the form of free amino acids, proteins, carbohydrates, vitamins, enzymes and mineral (Falco et al., 2003; Garcia et al., 2005; Ball 2007; Moniruzzaman et al., 2014).

The enrichment of mulberry leaves with honey and feeding to silkworm significantly enhanced the biological and economic characters of mulberry silkworm (Gad, 2013; Hassan et al., 2014; Saad et al., 2014; Hamzah et al., 2016; Alagumanikumaran and Prema, 2016; Madhavi et al., 2018) and transaminases activity (Thulasi and Sivaprasad, 2015). Transaminases or aminotransferases are a group of enzymes that catalyze the interconversion of amino acids and oxoacids by transfer of amino groups (David and Zafar, 1990). Though the published information on the modulatory role of honey on silkworm economic traits is available in plenty, the comparative performance of different honey and various protein sources on the silkworm metabolism is not adequately established. Keeping in view the high nutritional and medicinal status of honey, the studies were carried out to know the impact of honey from different bee species and protein sources on the carbohydrate and lipid content in haemolymph and fat body and the activity of transaminase enzymes in mulberry silkworm. 


\section{MATERIALS AND METHODS}

\section{Silkworm culturing}

Disinfection of rearing room and equipment was performed by spraying $0.05 \%$ Asthra solution containing high level of active chlorine at the rate of $140 \mathrm{~mL} / \mathrm{sq}$. ft. area before commencement of silkworm rearing (Sivaprasad et al., 2015). The Chawki larvae of popular bivoltine Double Hybrid silkworm were procured from the Chawki Rearing Centre. Rearing was taken up by feeding nutritious mulberry leaves three times a day, under suitable ecological conditions having the temperature of $26 \pm 2{ }^{\circ} \mathrm{C}$ and humidity of $80 \pm 5$ per cent. The mature worms were mounted using Netrika with the density of 70 larvae per sq. ft. (Dandin and Giridhar, 2014).

\section{Preparation of test solution and application of treatment}

The required concentrations of $1,2,3,4,5$ and 6 per cent of honey and protein sources were prepared by dissolving in distilled water. Weighed quantity of fresh mulberry leaves was sprayed with honey from five bee species, namely stingless bee honey, Indian bee honey, little bee honey, Italian bee honey and rock bee honey, and four protein sources such as redgram flour, horsegram flour, soya flour and pollen powder, separately. The honey of different bee species was procured from reliable sources. The raw redgram, horsegram and soyabean were roasted, ground into fine powder and sieved. The pollen pellets were collected from the bee colony using pollen trap and dried under shade.

One larval group fed on distilled water sprayed mulberry leaves and another larval group fed on mulberry leaves without any treatment (control) were maintained along with the experimental groups. The exogenous modulators sprayed leaves were shade dried for 30 minutes to remove the excess moisture and fed during third, fourth and fifth instars, once daily in the morning. The other feedings were provided with normal mulberry leaves. Each treatment was replicated thrice with 50 larvae per replication.

\section{Biochemical analysis}

\section{i) Estimation of carbohydrate}

Three larvae per replication were taken to collect the haemolymph and fat body. Anthrone method of Seifter et al. (1950) was used to determine carbohydrate content in the haemolymph. One $\mathrm{mL}$ of the sample was added with $2 \mathrm{~mL}$ of 10 per cent trichloroacetic acid and $8 \mathrm{~mL}$ of distilled water. The collected homogenates (haemolymph and fat body) were centrifuged at 4000 rpm for 15 minutes. After centrifugation, $1 \mathrm{~mL}$ of the supernatant was taken and each $4 \mathrm{~mL}$ of freshly prepared anthrone reagent was added. The tubes were covered with aluminium foil and kept in boiling water bath for 10 minutes. After cooling at room temperature, the colour intensity was read on the spectrophotometer at $620 \mathrm{~nm}$. Glucose was used as the reference standard. The carbohydrate content of fat body was expressed as $\mathrm{mg} / \mathrm{g}$ and haemolymph as $\mathrm{mg} / \mathrm{mL}$.

\section{ii) Estimation of lipids}

Three larvae per replication were taken to collect the haemolymph and fat body. The method of Folch et al. (1957) was used for lipid estimation, using chloroform methanol mixture (2:1). Haemolymph and fat body samples were homogenized with chloroform: methanol mixture in $1: 10$ ratio. The homogenate was then transferred to a $50 \mathrm{~mL}$ separating funnel and similar volume of chloroform was added. The two solvents were partitioned by the addition of 0.2 volume of water. After the funnel was shaken, the mixture was allowed to stand overnight. The lower chloroform layer containing lipid was drawn off. The lipid sample was kept in vacuum desiccators until constant weight was obtained. The lipid of fat body was expressed as $\mathrm{mg} / \mathrm{g}$ and haemolymph as $\mathrm{mg} / \mathrm{mL}$.

\section{iii) Estimation of transaminase enzyme activity}

\section{a. Glutamic Oxaloacetic Transaminase (GOT) or Aspartate aminotransferase (AST)}

The colorimetric method of Reitman et al. (1957) was used for the estimation of glutamic oxaloacetic transaminase (Aspartate transaminase), using GOT substrate (phosphate buffer + L-aspartate + ketoglutarate). Known quantity of haemolymph was collected in each test tube and $0.5 \mathrm{~mL}$ GOT substrate was added. After shaking, the tubes were kept in boiling water for $60 \mathrm{~min}$. Then, $0.5 \mathrm{~mL}$ of DNPH (dinitrophenylhydrazine) was added to the tubes and kept at room temperature. Finally, $5 \mathrm{~mL}$ of $\mathrm{NaOH}$ was added and allowed to stand for $5 \mathrm{~min}$ at room temperature. Then, the colour intensity was read on spectrophotometer at $503 \mathrm{~nm}$.

\section{b. Glutamic Pyruvic Transaminase (GPT) or Alanine aminotransferase (ALT)}

GPT substrate (phosphate buffer + L-alanine + ketoglutarate) was used for the estimation of glutamic pyruvic transaminase (Alanine transaminase). The haemolymph was collected and GPT was quantified by adopting standard procedure (Reitman et al., 1957) as described in the estimation of glutamic oxaloacetic transaminase.

\section{iv) Statistical analysis}

The data collected from the experiments were statistically analyzed in Factorial Completely Randomised Design (FCRD) as described by Panse and Sukhatme (1957). 


\section{RESULT AND DISCUSSION}

The application of various honey and protein sources to silkworm larvae during the late-age stages elucidated notable changes in the metabolic activity of silkworm. This was evident from the level of variation in the carbohydrate and lipid in haemolymph and fat body, and activity of aminotransferase enzymes.

\section{Haemolymph carbohydrate}

The oral application of honey and protein sources to silkworm larvae through mulberry leaves greatly improved the level of haemolymph carbohydrate (Fig. 1). In respect of treatments, T. iridipennis honey significantly increased the carbohydrate content of haemolymph to $15.57 \mathrm{mg} / \mathrm{mL}$ from $11.44 \mathrm{mg} / \mathrm{mL}$ in control. This was followed by soya flour (14.13 $\mathrm{mg} / \mathrm{mL})$, A. florea honey $(14.00 \mathrm{mg} / \mathrm{mL})$, A. mellifera honey $(13.99 \mathrm{mg} / \mathrm{mL})$, A. dorsata honey $(13.97 \mathrm{mg} /$ $\mathrm{mL}) A$. cerana honey $(13.86 \mathrm{mg} / \mathrm{mL})$ and red gram flour $(13.85 \mathrm{mg} / \mathrm{mL})$, which showed statistical parity with each other. Among the concentrations, the highest amount of haemolymph carbohydrate was recorded in 5 per cent $(14.07 \mathrm{mg} / \mathrm{mL})$, which was found to be on par with $6(13.84 \mathrm{mg} / \mathrm{mL})$ and 4 $(13.78 \mathrm{mg} / \mathrm{mL})$ per cent. The lowest haemolymph carbohydrate was registered in 1 per cent (13.11 $\mathrm{mg} / \mathrm{mL}$ ). In the interaction between concentrations and treatments, significantly more quantity of haemolymph carbohydrate was observed in 5 per cent $T$. iridipennis honey $(16.71 \mathrm{mg} / \mathrm{mL})$, which exhibited statistical parity with $6(16.08 \mathrm{mg} / \mathrm{mL})$ and $4(15.98 \mathrm{mg} / \mathrm{mL})$ per cent of $T$. iridipennis honey. The next best treatments were $3(15.98 \mathrm{mg} / \mathrm{mL})$ and 2 (15.17 mg/mL) per cent of T. iridipennis honey and 5 per cent $A$. dorsata honey $(14.89 \mathrm{mg} / \mathrm{mL})$.

Fig 1. Impact of different honey and protein sources on haemolymph carbohydrate

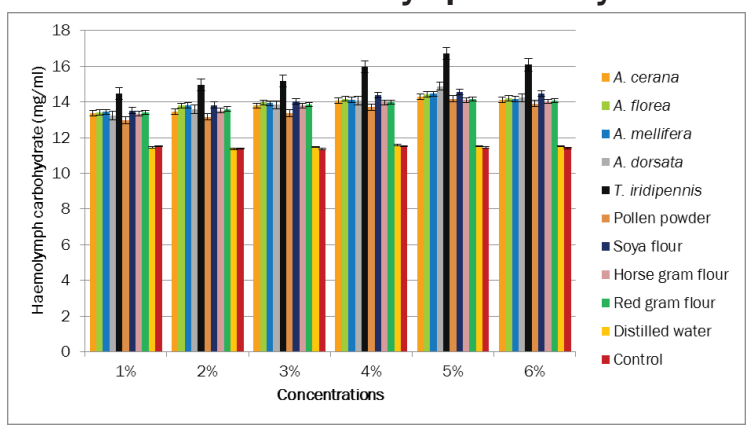

The present observations can be corroborated with the findings of Saravanan et al. (2021), who recorded significantly higher haemolymph glucose content $(14.99 \pm 0.80 \mathrm{mg} / \mathrm{mL})$ than the control $(13.09 \pm 0.70 \mathrm{mg} / \mathrm{mL})$, when the late-age silkworm was fed on mulberry leaves treated with extract of cowpea, Vigna unguiculata at 7.5 per cent concentration. Further, Bhattacharya and Kaliwal (2005) observed that the oral supplementation of potassium and magnesium chloride at $150 \mu \mathrm{g} / \mathrm{mL}$ to fifth instar silkworm larvae once on an alternate day resulted in an increase of 44 per cent haemolymph trehalose over the untreated larvae. Kavitha et al. (2014) found that the oral application of zinc chloride at 100 ppm to silkworm larvae through mulberry leaves during fourth and fifth instar daily once in the evening led to significant increase in haemolymph carbohydrate level to $33.70 \mathrm{mg} / \mathrm{mL}$ from $24.0 \mathrm{mg} / \mathrm{mL}$ in control. These results conform with the present observations.

\section{Fat body carbohydrate}

Carbohydrate content of fat body considerably varied between treatments, significantly highest being in T. iridipennis honey $(12.07 \mathrm{mg} / \mathrm{g})$ followed by soya flour (10.41 mg/g) (Fig. 2). The treatments $A$. florea honey (10.11 mg/g), A. mellifera honey (10.06 $\mathrm{mg} / \mathrm{g}$ ) and $A$. dorsata honey $(10.03 \mathrm{mg} / \mathrm{g})$ were found to be on par with each other. Least amount of fat body carbohydrate was observed in control (7.89 $\mathrm{mg} / \mathrm{g}$ ). Regarding various concentrations studied, the highest level of fat body carbohydrate was registered in 5 percent $(9.99 \mathrm{mg} / \mathrm{g})$, which showed statistical superiority over all other concentrations. This was followed by 4 per cent $(9.84 \mathrm{mg} / \mathrm{g})$, which was found to be on par with 6 per cent $(9.82$ $\mathrm{mg} / \mathrm{g})$. One per cent showed least amount of fat body carbohydrate $(9.62 \mathrm{mg} / \mathrm{g})$. In the interaction between treatments and concentrations, 5 per cent T. iridipennis honey recorded maximum quantity of fat body carbohydrate $(12.38 \mathrm{mg} / \mathrm{g})$, which was found to be on par with $6(12.23 \mathrm{mg} / \mathrm{g})$ and 4 (12.21 $\mathrm{mg} / \mathrm{g}$ ) per cent of $T$. iridipennis honey. The next better treatments were 3 (12.03 mg/g), 2 (11.83 mg/g) and $1(11.71 \mathrm{mg} / \mathrm{g})$ per cent of T. iridipennis honey.

Fig 2. Impact of different honey and protein sources on fat body carbohydrate

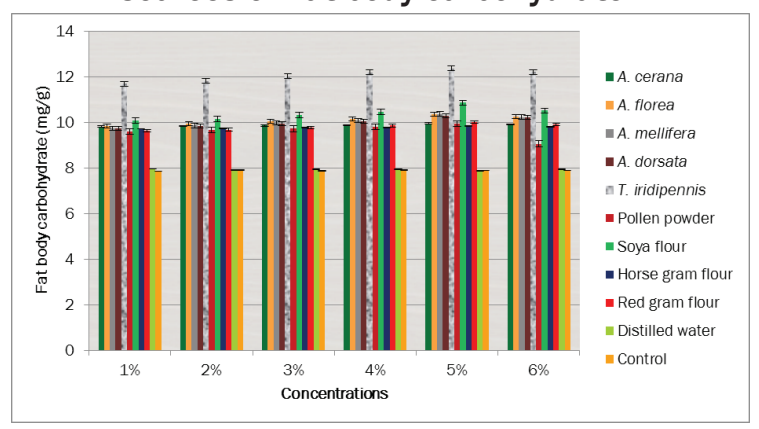

This falls in line with Bhattacharya and Kaliwal (2005) findings, who registered increased fat body glycogen, when the fifth instar silkworm was orally supplemented with potassium and magnesium chloride at $150 \mu \mathrm{g} / \mathrm{mL}$. Further, the present observations are supported by Kavitha et al. (2014), who reported that enrichment of mulberry leaves with 100 ppm zinc chloride and feeding to silkworm larvae from the first day of fourth instar to spinning 
significantly enhanced the carbohydrate in fat body $(122.00 \mathrm{mg} / \mathrm{g})$ by 82.90 per cent over the control (66.70 mg/g). Moreover, the findings of Thilsath et al. (2016) revealed that soya flour supplementation, increased the carbohydrate content of fat body compared to control also strengthens the present result of soya flour performing better, next to honey.

\section{Haemolymph lipid}

The lipid content of haemolymph showed significant variation when silkworm was reared by supplementing with honey and protein sources (Fig. 3). Among the treatments, the highest haemolymph lipid content was observed in T. iridipennis honey $(22.52 \mathrm{mg} / \mathrm{mL})$, which exhibited statistical superiority over all other treatments. This was followed by soya flour (21.38 $\mathrm{mg} / \mathrm{mL})$, A. florea honey $(20.22 \mathrm{mg} / \mathrm{mL})$, A. mellifera honey $(19.76 \mathrm{mg} / \mathrm{mL})$, $A$. dorsata honey $(19.42 \mathrm{mg} /$ $\mathrm{mL})$ and $A$. cerana honey $(19.35 \mathrm{mg} / \mathrm{mL})$, which showed statistical variation among themselves. Silkworm fed with untreated leaves registered the least amount of haemolymph lipid $(17.67 \mathrm{mg} / \mathrm{mL})$. Among the different concentrations, significantly maximum haemolymph lipid content of $19.81 \mathrm{mg} /$ $\mathrm{mL}$ was registered in 5 per cent. The next better concentrations were $6(19.67 \mathrm{mg} / \mathrm{mL}), 4$ (19.58 $\mathrm{mg} / \mathrm{mL}), 3(19.48 \mathrm{mg} / \mathrm{mL})$ and $2(19.42 \mathrm{mg} / \mathrm{mL})$ per cent. The lowest haemolymph lipid was observed in 1 per cent ( $19.34 \mathrm{mg} / \mathrm{mL}$ ). The interaction between concentrations and treatments revealed that the highest haemolymph lipid content was recorded in 5 per cent $T$. iridipennis honey $(23.03 \mathrm{mg} /$ $\mathrm{mL}$ ), however, this was found to be on par with 6 $(22.81 \mathrm{mg} / \mathrm{mL})$ and $4(22.67 \mathrm{mg} / \mathrm{mL})$ per cent of $T$. iridipennis honey.

Fig 3. Impact of different honey and protein sources on haemolymph lipid

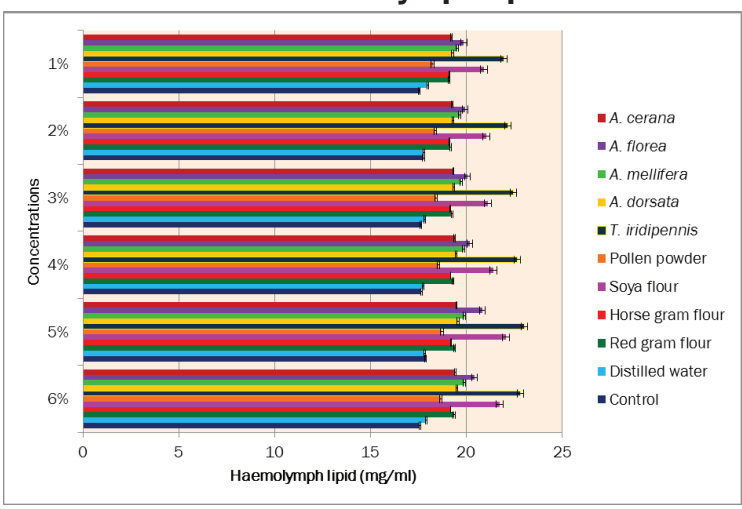

The findings of Manjula et al. (2010) showing that the per os administration of seed extract of Indian bean, $D$. lablab at 7.5 per cent to silkworm larvae, 5 times/day starting from third to fifth instar significantly improved the haemolymph cholesterol content to $38.36 \pm 2.05$ from $30.36 \pm 1.38 \mathrm{mg} / \mathrm{mL}$ in control, falls more or less in line with the present result. Further, the report of Saravanan et al. (2021) revealed that the application of cowpea extract (7.50 $\%)$, during late-age instar significantly increased haemolymph cholesterol, also in parity with the present result.

\section{Fat body lipid}

The present study revealed that there were significant changes in the fat body lipid content due to the application of honey and protein sources (Fig. 4). , The maximum amount of fat body lipid, was recorded in T. iridipennis honey $(43.78 \mathrm{mg} / \mathrm{g})$, which was found to be statistically superior over all other treatments. The next better treatments were soya flour (42.71 mg/g), A. florea honey (42.59 $\mathrm{mg} / \mathrm{g})$, A. mellifera honey (42.23 mg/g) A. dorsata honey $(42.11 \mathrm{mg} / \mathrm{g})$, which did not show statistical variation among themselves. Control recorded the least amount of fat body lipid (37.67 mg/g). Among the concentrations evaluated, statistically greater level of fat body lipid was observed in 5 per cent $(42.16 \mathrm{mg} / \mathrm{g})$, which was followed by 6 (41.85 mg/g), 4 (41.37 mg/g), 3 (41.05 mg/g) and $2(40.53 \mathrm{mg} / \mathrm{g})$ per cent. Minimum amount of fat body lipid was registered in 1 per cent $(40.09 \mathrm{mg} / \mathrm{g}$ ). In the interaction between different treatments and concentrations, the highest fat body lipid was noticed in 5 per cent $T$. iridipennis honey (45.38 $\mathrm{mg} / \mathrm{g})$, which was found to be on par with 5 per cent soya flour (44.32 mg/g), 6 (44.31 mg/g) and 4 (44.18 mg/g) per cent T. iridipennis honey, and 6 per cent soya flour (44.17 mg/g).

Fig 4. Impact of different honey and protein sources on fat body lipid

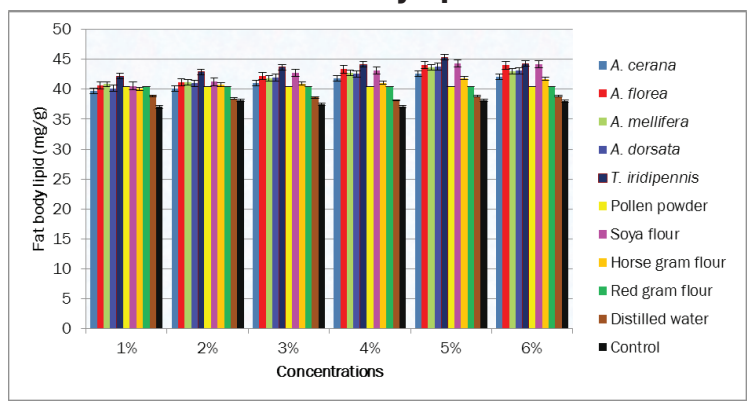

The observation of Bhattacharya and Kaliwal (2005) showing that fortification of mulberry leaves with potassium and magnesium chloride at $50 \mathrm{\mu g} / \mathrm{mL}$ to fifth instar silkworm larvae once on an alternate day resulted in an increase of 25 per cent fat body lipids compared to the control, falls in line with the present finding. In addition to this, the report showing that the silkworm larvae fed on soya flour treated mulberry leaves enhanced the lipid content of fat body (Thilsath et al., 2016), substantiates the present finding of soya flour recording more fat body lipid, next to honey. 


\section{Glutamic Oxaloacetic Transaminase (GOT) or Aspartate aminotransferase (AST)}

Silkworm fed on mulberry leaves sprayed with different honey and protein sources showed marked variations regarding AST activity (Table 1 ). Among the treatments, $T$. iridipennis honey recorded statistically greater level of AST enzyme activity of $252.31 \mu \mathrm{g} / \mathrm{mL}$ than all other treatments. This was followed by soya flour $(249.47 \mu \mathrm{g} / \mathrm{mL})$, A. florea honey (244.97 $\mu \mathrm{g} /$ $\mathrm{mL})$, A. mellifera honey (242.02 $\mathrm{\mu g} / \mathrm{mL})$, A. dorsata honey $(231.43 \mu \mathrm{g} / \mathrm{mL})$ and $A$. cerana honey (229.58 $\mu \mathrm{g} / \mathrm{mL})$. The minimum activity of AST enzyme was registered in control $(224.27 \mu \mathrm{g} / \mathrm{mL})$. In respect of different concentrations, AST activity was noticed to be significantly more in 5 per cent $(239.89 \mu \mathrm{g} / \mathrm{mL})$. The next better concentrations were $6(238.01 \mu g /$ $\mathrm{mL}), 4(235.98 \mu \mathrm{g} / \mathrm{mL})$ and $3(233.94 \mu \mathrm{g} / \mathrm{mL})$ per cent. The lowest level of AST was observed in 1 per cent $(230.53 \mu \mathrm{g} / \mathrm{mL})$. In the interaction between the treatments and concentrations, significantly higher AST activity was registered in 5 per cent $T$. iridipennis honey $(269.78 \mu \mathrm{g} / \mathrm{mL})$ than all other treatments.
This was followed by 5 per cent soya flour (264.24 $\mu \mathrm{g} / \mathrm{mL}), 6$ per cent $T$. iridipennis honey $(260.65 \mu \mathrm{g} /$ $\mathrm{mL}), 6$ per cent soya flour $(258.66 \mu \mathrm{g} / \mathrm{mL})$ and 4 per cent $T$. iridipennis honey $(254.36 \mu \mathrm{g} / \mathrm{mL})$.

This result strengthened with the findings of Khedr et al. (2013) and Hassan et al. (2014), who reported that application of 5 per cent honey to silkworm during late-age instars significantly increased the AST activity. The supplementation of 7.5 per cent seed extract of $V$. unguiculata to silkworm from during third, fourth and fifth instars significantly enhanced the activity of AST to $420.67 \pm 22.57 \mathrm{IU} / \mathrm{L}$ from 390.21 $\pm 18.22 \mathrm{IU} / \mathrm{L}$ in the untreated larvae (Saravanan et al., 2021), which can also be comparable with the present results. Apart from this, the present observations on the performance of soya flour are in accordance with findings of Anil Kumar and Prashanth (2018), who registered that oral application of 6 per cent soya flour greatly increased the AST activity $(278.56 \mu \mathrm{g} /$ $\mathrm{mL}$ ) in CSR4 silkworm breed compared to control (164.36 $\mu \mathrm{g} / \mathrm{mL})$.

Table 1. Impact of different honey and protein sources on Aspartate aminotransferase $(\mu \mathrm{g} / \mathrm{mL})$

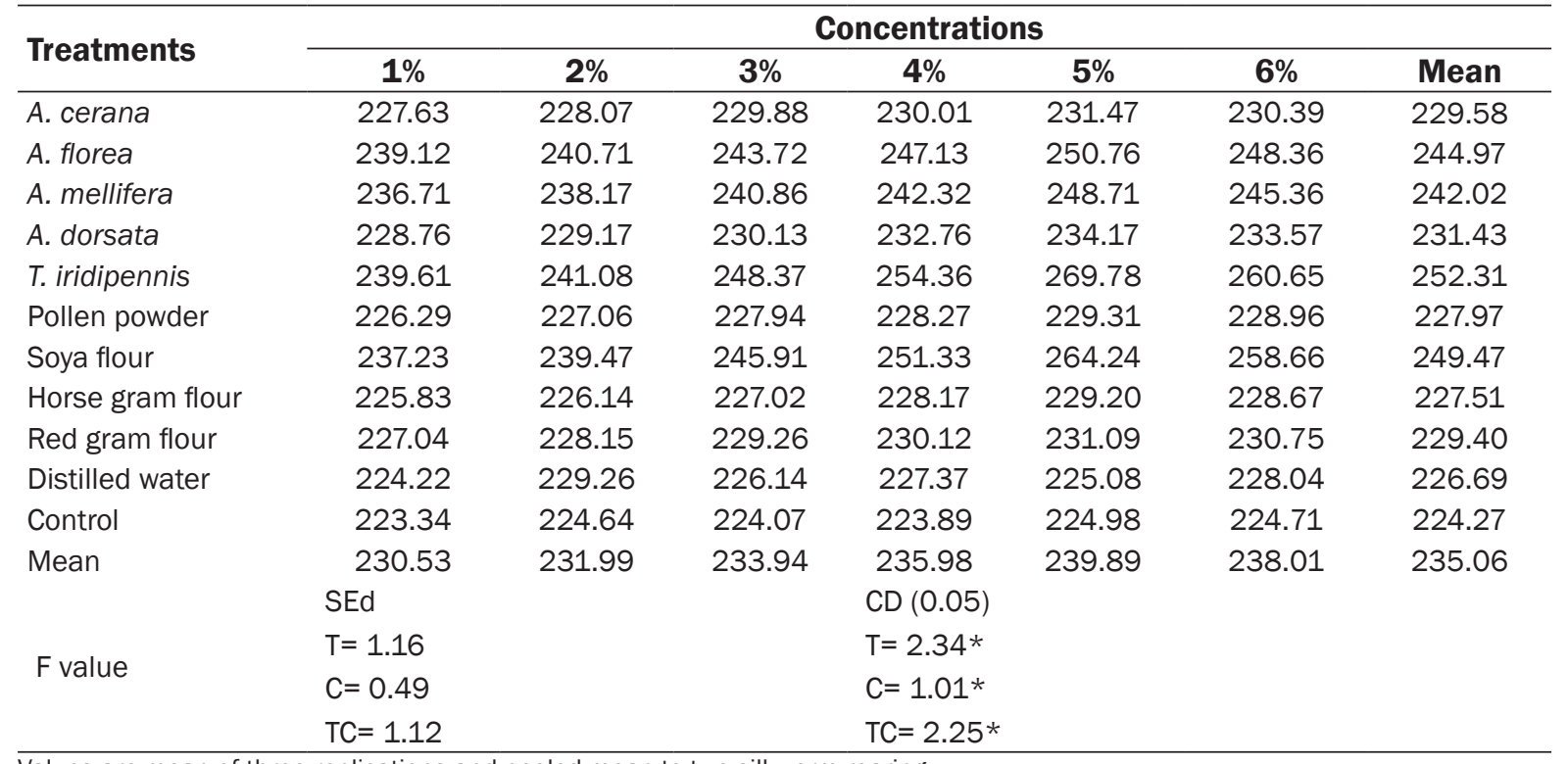

Values are mean of three replications and pooled mean to two silkworm rearing.

$\mathrm{T}$ - Treatment, C - Concentration, * Significant

\section{Glutamic Pyruvic Transaminase (GPT) or Alanine aminotransferase (ALT)}

The application of honey from different bee species and protein sources resulted in elevated level of ALT enzyme activity in silkworm (Table 2). The ALT activity was significantly the highest in $T$. iridipennis honey $(553.44 \mu \mathrm{g} / \mathrm{mL})$, which showed statistical superiority the control $(497.85 \mu \mathrm{g} / \mathrm{ml})$. The next better treatments were in the order of soya flour (547.24 $\mu \mathrm{g} / \mathrm{mL})$, A. florea honey $(540.85 \mu \mathrm{g} / \mathrm{mL})$, A. mellifera honey $(537.54 \mu \mathrm{g} / \mathrm{mL})$ and $A$. dorsata honey $(531.64 \mu \mathrm{g} / \mathrm{mL})$, which exhibited statistical variation among themselves. Among the different concentrations, 5 per cent registered the highest ALT activity of $528.94 \mu \mathrm{g} / \mathrm{mL}$, followed by $6(528.40$ $\mu \mathrm{g} / \mathrm{mL}), 4$ (526.10 $\mu \mathrm{g} / \mathrm{mL}), 3(523.95 \mu \mathrm{g} / \mathrm{mL})$ and $2(522.36 \mu \mathrm{g} / \mathrm{mL})$ per cent. The least ALT activity was registered in 1 per cent $(519.36 \mu \mathrm{g} / \mathrm{mL})$. The interaction between treatments and concentrations revealed that 5 per cent $T$. iridipennis honey showed maximum alanine aminotransferase activity 563.25 $\mu \mathrm{g} / \mathrm{mL}$, which exhibited statistical parity with 6 per cent $T$. iridipennis honey $(561.18 \mu \mathrm{g} / \mathrm{mL})$. The treatments, 5 per cent soya flour $(558.73 \mu \mathrm{g} / \mathrm{mL})$ and 4 per cent $T$. iridipennis honey $(556.25 \mu \mathrm{g} / \mathrm{mL})$ were found to be on par with each other. 
The present observations are in conformity with results of Khedr et al. (2013) and Hassan et al. (2014), who recorded that supplementation of honey at 5 per cent on mulberry leaves significantly enhanced the ALT activity in silkworm haemolymph. Further, the findings of Manjula et al. (2010), who showed that the enrichment of mulberry leaves with 7.5 per cent seed extract of D. lablab and feeding to silkworm during late-age significantly elevated the activity of ALT $(440.02 \pm 23.62 \mathrm{IU} / \mathrm{L})$ over the untreated larvae $(390.22 \pm 18.21 \mathrm{IU} / \mathrm{L})$, also fall in line with the present observations. Increased activity of ALT (518.01 $\mathrm{mg} / \mathrm{mL}$ ) was observed, when the larvae of silkworm breed, CSR2 was fed on mulberry leaves treated with 4 per cent soya flour (Anil Kumar and Prashanth, 2018). This report can also corroborate the present result of soya flour performing well, next to honey.

Table 2. Impact of different honey and protein sources on Alanine aminotransferase $(\mu \mathrm{g} / \mathrm{mL})$

\begin{tabular}{|c|c|c|c|c|c|c|c|}
\hline \multirow{2}{*}{ Treatments } & \multicolumn{7}{|c|}{ Concentrations } \\
\hline & $1 \%$ & $2 \%$ & $3 \%$ & $4 \%$ & $5 \%$ & $6 \%$ & Mean \\
\hline A. cerana & 525.41 & 528.52 & 529.72 & 529.95 & 531.07 & 530.15 & 529.14 \\
\hline A. florea & 537.53 & 538.12 & 540.01 & 541.25 & 545.81 & 542.37 & 540.85 \\
\hline A. mellifera & 533.22 & 534.14 & 535.21 & 539.48 & 542.27 & 540.91 & 537.54 \\
\hline A. dorsata & 524.17 & 526.78 & 527.39 & 531.81 & 540.91 & 538.75 & 531.64 \\
\hline T. iridipennis & 540.29 & 548.37 & 551.28 & 556.25 & 563.25 & 561.18 & 553.44 \\
\hline Pollen powder & 511.57 & 511.73 & 511.91 & 512.07 & 512.38 & 512.34 & 512.00 \\
\hline Soya flour & 538.25 & 540.11 & 542.76 & 550.33 & 558.73 & 553.26 & 547.24 \\
\hline Horse gram flour & 523.37 & 525.17 & 528.83 & 531.21 & 535.62 & 532.21 & 529.40 \\
\hline Red gram flour & 518.15 & 519.08 & 520.28 & 521.81 & 522.19 & 521.63 & 520.52 \\
\hline Distilled water & 482.40 & 479.92 & 492.30 & 486.97 & 484.81 & 490.41 & 486.14 \\
\hline Control & 478.61 & 491.26 & 483.72 & 485.92 & 481.23 & 489.19 & 484.99 \\
\hline Mean & 519.36 & 522.11 & 523.95 & 526.10 & 528.94 & 528.40 & 524.81 \\
\hline \multirow{4}{*}{ F value } & SEd & & & CD (0.05) & & & \\
\hline & $T=0.68$ & & & $\mathrm{~T}=1.37 * *$ & & & \\
\hline & $C=0.26$ & & & $C=052 * *$ & & & \\
\hline & $\mathrm{TC}=2.05$ & & & $\mathrm{TC}=4.12^{* *}$ & & & \\
\hline
\end{tabular}

Values are mean of three replications and pooled mean to two silkworm rearing.

T - Treatment, C - Concentration, * Significant, **Highly significant

\section{CONCLUSION}

From the present experiments, it is crystal clear that the fortification of mulberry leaves with different honey and protein sources significantly altered the metabolic processes in B. mori. Among the various sources and concentrations evaluated, T. iridipennis honey at five per cent showed statistical superiority by registering highest carbohydrate $(16.71 \mathrm{mg} /$ $\mathrm{mL}$ and $12.38 \mathrm{mg} / \mathrm{g})$ and lipid content (23.03 $\mathrm{mg} / \mathrm{mL}$ and $45.38 \mathrm{mg} / \mathrm{g}$ ) in the haemolymph and fat body, respectively over all other treatments. $T$. iridipennis honey in the same concentration was also significantly increased the activity of Aspartate aminotransferase $(269.78 \mu \mathrm{g} / \mathrm{mL})$ and Alanine aminotransferase $(563.25 \mu \mathrm{g} / \mathrm{mL})$ enzymes.

\section{Ethics statement}

No specific permits were required for the described field studies because no human or animal subjects were involved in this research.

\section{Originality and plagiarism}

We assure that we have written and submitted only entirely original works.

\section{Consent for publication}

All the authors are agreed to publish this research article.

\section{Competing interests}

There were no conflict of interest in the publication of this content

\section{Data availability}

All the data of this manuscript are included in the MS. No separate external data source is required. If anything is required from the MS, certainly, this will be extended by communicating with the corresponding author through corresponding official mail: arunaramaiah07@gmail.com

\section{REFERENCES}

Alagumanikumaran, N. and P. Prema. 2016. Studies on evaluation and improvements of growth and economic parameters of Bombyx mori L. influence under MR2 leaves fortified with natural honey. Int. J. Curr. Sci. Res., 2(6):757-765.

Anil Kumar, M. N. and J. Prashanth. 2018. Influence of mulberry leaf with soyabean flour supplemention on the economic traits and amino transferases activity in Bombyx mori L. Int. J. Zool. Stud., 3(2) : 59-64.

Council of European Union. 2002. Council Directive 2001/110/Ec of 20 December 2001 relating to honey. Offic. J. the. Europ. Comm., LIO. p.47-52.

Ball, D.W. 2007. The chemical composition of honey. J. Chem. Education., 84(10) : 1643.

$107 \mid 10-12$ | 6 
Bhattacharya, A. and B. B. Kaliwal. 2005. Synergetic effects of potassium and magnesium chloride on biochemical contents of the silkworm, Bombyx mori L., Caspian J. Env. Sci., 3(1) : 15-21.

Dandin, S. B. and K. Gridhar. 2014. Handbook of Sericulture Technologies. Central Silk Board, Bangalore. pp 315-325.

Etebari, K., Kaliwal, B. B. and L. Matindoost. 2004. Different aspects of mulberry leaves supplementation with various nutritional compounds in sericulture. Int. J. Indust. Entomol., 9 : 15-28.

Falco, G., Gomez-Catalan, C., Llobet, J. M. and J. L. Domingo. 2003. Contribution of medicinal plants to the dietary intake of various toxic elements in Catalonia, Spain. Trace Elem. Electrolytes., 20 : $120-124$.

Folch, J., Lees, M. and G. H. Sloane Stanley. 1957. A simple method for the isolation and purification of total lipides from animal tissues. J. Biol. Chem., 226(1) : 497 - 509.

Gad, A. A. 2013. Biological and Physiological Effects of Some Honey Bee Products and Its Mixtures as Nutritional Additives on Two Strains of The Mulberry Silkworm Bombyx mori. Alexandria J. Agric. Res., 58(1) : 47 - 52.

Garcia, J. C. R., Garcia, J. B., Latorre, C. H., Martin, S. G. and R. M. P. Crecent. 2005. Comparison of Palladium- magnesium nitrate and ammonium dihydrogen phosphate modifiers for lead determination in honey by electrothermal atomic absorption modifiers spectrometry. Food Chem., $91: 435-439$.

Hamzah, M., Kamel, F., Abo-Laban, G. and M. M. Nabil. 2016. The effect of mulberry leaves enrichment with different nutritional supplements on biological aspects and economic traits of silkworm, Bombyx mori (L.). Annals of Agric. Sci. Moshtohor., 54(4) : 977 - 982.

Hassan, E. M., Ebrahem, M. S. and R. H. Taha 2014. Study of physiological and biochemical changes in mulberry silkworm feeding on mulberry leaves supplemented with camphor honey and oil. J. Plant Prot. and Path., 5(9) : 855 - 864.

Kantwa, S. C., Gupta, L., Singh, B. P. and S. P. Tailor. 2006. Nutritional evaluation of mulberry (Morus alba L.) green leaves in sheep and goats. Indian J. Small Ruminants., 12(2) : 202 - 205.

Kavitha, S., Srinivasamurthy, S., Saidullah, B. and K. Yellamma. 2014. Total carbohydrates and economic parameters of Bombyx mori under the influence of zinc chloride - enriched mulberry diet, Int. J. Pure App. Biosci., 2(5) : 196 - 202.

Khan, M. D. and B. N. Saha. 1995. Growth and development of the mulberry silkworm, Bombyx mori $L$. on feed supplemented with alanine and glutamine. Sericologia., 35 : 657-663.

Khedr, M. M. A., Samah, N., Shafiey, E. and H. M. I. Mead. 2013. Influence of fortification of mulberry leaves with natural and synthetic multivitamins on growth and development of Bombyx mori L. J. Plant Prot. and Path., 4(1) : 111 - 123.

Madhavi, R., Arivoli, S. and S. Sivaprasad. 2018. Determination of minimum effective concentration of honey that optimizes larval growth and silk production in the silkworm, Bombyx mori. Int. J. Green and Herbal Chem., 7(3) : 477 - 488.

Manjula, S., Sabhanayakam, S., Mathivanan, V. and N. Saravanan. 2010. Biochemical alterations in the haemolymph of silkworm [Bombyx mori $L$. (Lepidoptera: Bombycidae)] fed with mulberry leaves enriched with Indian bean (Dolichos lablab). Recent Res. in Sci. and Tech., 2(3) : 32-37.

Moniruzzaman, M., Yungan, C., Rao, P. V., Hawlader, M. N. I., Azlan, S. A. B. M., Sulaiman, S. A. and S. H. Gan. 2014. Identification of phenolic acids and flavonoids in monofloral honey from Bangladesh by high performance liquid chromatography: determination of antioxidant capacity. Bio. Med. Res. Int., 1 : 11.

Panse, V. G. and P. V. Sukhatme. 1957. Statistical methods for agricultural workers. ICAR publication, $328 \mathrm{p}$.

Rahmathulla, V. K., Das, P., Ramesh, M. and R. K. Rajan. 2007. Growth rate pattern and economic traits of silkworm, Bombyx mori. L. under the influence of folic acid administration. J. Appl. Sci. Environ. Manage., 11(4) : 81 - 84.

Reitman, S., Stanley, R. and S. Frankel. 1957. A colorimetric method for the determination of serum glutamic oxalacetic and glutamic pyruvic transaminases. American J. Clinical Path., 28(1) : $56-63$.

Saad, M. S. I., Hassan, E. M. and I. A. I. Saad. 2014. Comparative study of the effect of camphor honey bee and camphor oil on some biological and productivity characters of mulberry silkworm, Bombyx mori L. J. Plant Prot. and Path., 5(5) : $651-658$.

Saravanan, M., Selvi, S., Veeranarayanan, M. and S. Nadanam. 2021. Modulations in the haemolymph of silkworm [Bombyx mori L. (Lepidoptera: Bombycidae)] fed with mulberry leaves augmented with cowpeas (Vigna unguiculata), Int. J. Nutrition, Pharmacology and Neurological Diseases., 1(1) : 6468.

Seidavi, A. R., Bizhannia, A. R., Sourati, R. and M. Mavvajpour. 2005. The nutritional effects of different mulberry varieties on biological characters in silkworm. Asia. Pac. J. Clin. Nutr., $14: 122$ 124.

Seifter, S., Dayton, S., Novic, B. and E. Muntwyler. 1950. The estimation of glycogen with the anthrone reagent. Arch. Biochem., 25 : 191 - 200.

Sivaprasad, V., Himantharaj, M. T., Verma, S. and T. Mogiti. 2015. Commercial Chawki Rearing, Central Sericultural Research \& Training Institute, CSB, Mysuru, p.13.

Thilsath, F. Q., Kumari, M., Bai, P. K. K. and M. Ramanibai. 2016. Impact of plant and animal proteins in biochemical contents and economic traits of Bombyx mori. L. Indian J. Curr. Res., 8(12) : 42752 - 42757.

Thulasi, N. and S. Sivaprasad. 2015. Larval growth, silk production and economic traits of Bombyx mori under the influence of honey-enriched mulberry diet. J. App. and Natural Sci., 7(1) : 286 - 292.

$107 \mid 10-12$ | 7 